\title{
Climate Comfort Analysis for Tourism in Samosir District
}

\author{
Adhityo Haryadi ${ }^{1}$, Eko Kusratmoko ${ }^{2}$, Asep Karsidi ${ }^{2}$
}

\author{
${ }^{1}$ Student of Magister of Geography, Geography Department, Universitas Indonesia, Indonesia \\ ${ }^{2}$ Lecturer of Magister of Geography, Geography Department, Universitas Indonesia, Indonesia
}

\begin{abstract}
Tourism has become one of the sectors which are the mainstay source of foreign exchange in Indonesia. One of the region which has tourism potential is Samosir District at North Sumatra Province. Climatic conditions affect the tourist comfortability while doing the tourism activity. Studies on climate comfort in Toba Lake Region, especially in Samosir District have not been done. Way to determine the level of comfort associated with tourism activities are known to the Tourism Climate Index (TCl). This research aims to determine the level of climate comfort tourist destinations in Samosir District based on the value of $\mathrm{TCl}$ and knowing the relation between $\mathrm{TCl}$ value with the number of visits a tourist destination. Keyword: Climate, $\mathrm{TCl}$, and Tourism
\end{abstract}

\section{Introduction}

The tourism sector is one of Indonesia's mainstays in generating foreign exchange. This is reinforced by the diversity of cultures and tribes that attract tourists to come. According to the Ministry of Tourism, in 2017 the tourism sector generates foreign exchange of US \$ 17 billion (Gumelar, 2017). Not only natural attractions that become an attraction, but also the diversity of human beings which shows that Indonesia is rich in culture, ranging from tribes, races, and customs that have become unique and unique in the Indonesian tourism industry.

Comfort consists of psychological comfort and physical comfort. Psychic comfort namely psychological comfort (feeling safe, calm, happy, etc.) that is measured subjectively (qualitatively). Whereas physical comfort can be measured objectively (quantitatively); which includes spatial, visual, auditory and thermal comfort (Rilatupa, 2008). According to Lippsmeir (1994) the comfort limit for equatorial conditions is in the air temperature range of $22.5^{\circ} \mathrm{C}-29^{\circ} \mathrm{C}$ with air humidity of $20-50 \%$.

Samosir Regency has climate conditions will certainly support tourism activities. Tourists feel comfortable doing tourism activities in Samosir Regency. Samosir Regency is one of the districts in North Sumatra Province that has potential in the tourism sector. Samosir Regency which is supported by the existence of Lake Toba recorded an increase in the number of tourists from 2008 to 2013. In 2008 tourists amounted to 105,971, and continued to increase until 2013 tourists reached 149,414 (Tourism Office of Samosir Regency, 2014).

Mieczkowski (1985) has developed a measurement method as a climate comfort parameter with the Tourism Climate Index (TCI). TCI calculations use several climate variables that are relevant to tourism activities, namely: 1) air temperature, 2) air humidity, 3) rainfall, 4) duration of solar radiation, and 5) wind speed. This method is designed for climate comfort studies for tourism in Europe. Applying this method to tropical climate is still very lack. TCI is very helpful in identifying the comfort level of tourist destinations based on climate conditions.

The results of the analysis based on the TCI method can be useful as one of the information on the schedule of visits for tourists with a low level of climate risk in carrying out tourism activities in Samosir Regency. Some of the objectives in this study were to analyze the comfort level of climate in Lake Toba based on the Tourism Climate Index method, provide information for visitors about the right time for visitors to come to Samosir Regency, and analyze the influence of climate comfort level on the number of visitors in Samosir Regency.

\section{Study area}

The research was performed on the Samosir District (Fig.1). Astronomically, Samosir Regency is located at Latitude $20^{\circ} 24^{\prime}-20^{\circ} 25^{\circ} \mathrm{N}$ and Longitude $98^{\circ} 21$ '$99^{\circ} 55^{\circ} \mathrm{E}$. Its western position is located on the mainland of Sumatra, and its eastern part is on Samosir Island in the middle of Lake Toba. Samosir Regency which is in a tropical climate is very beneficial because it makes the region always illuminated by the sun throughout the year and has high rainfall during the rainy season so that it has fertile land and is overwhelmed by extraordinary nature. The average blowing wind is medium speed. The air temperature is not too low and not too high around $17{ }^{\circ} \mathrm{C}$ - $29{ }^{\circ} \mathrm{C}$ with an average humidity of $85 \%$. The cool air temperature can certainly support the development of tourism.

The astronomical location of Samosir which is in a tropical climate causes Samosir to still have the influence of the moonson wind from Asia. This Asian moonson wind brings considerable rainfall. So that hydrologically, it has a large potential of water reserves. In addition, temperatures that are quite stable in the tropics cause the vegetation of tropical rainforests to thrive well.

* Adhityo Haryadi: adhityohar@yahoo.com 


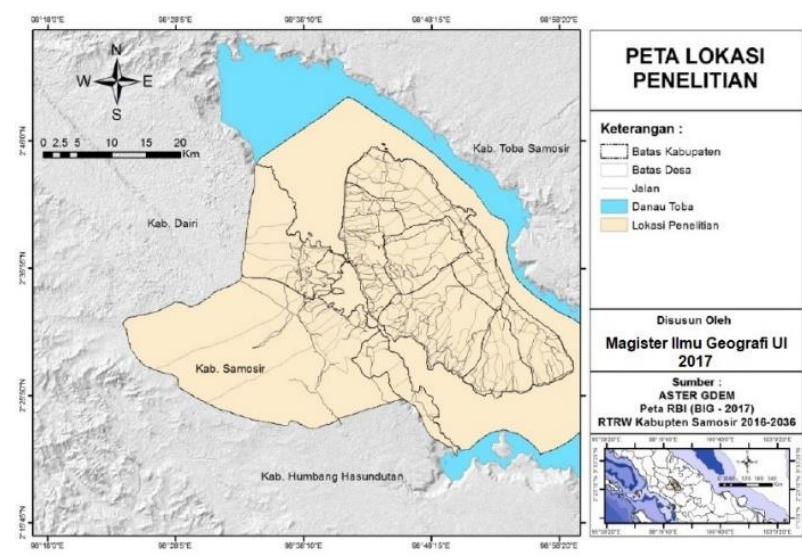

Figure 1. Maps of Research Location

\section{Literature Review}

\section{Climate and Tourism}

Climate is one of the important natural factors that is a concern for tourists. According to Aguiló et al. (2005) climate is one of the main drivers in international tourism, as most tourists look for opportunities to relax in the sun or snow. Tourists generally look for tourist attractions with climate conditions that are more comfortable and different compared to the conditions of the climate where they live. Each climate parameter has its own influence on tourists.

The use of climate information in the tourism sector is used by three main users, namely tourists, tourism developers and also government institutions. For tourists, weather forecasts in tourist destinations and weather conditions are very important for tourists. Then for tourism developers, existing climate information is useful for strategic planning for infrastructure development. As for government institutions, climate information is used to identify climate change risks and as a reference for future mitigation programs (Scoot and Lemieux, 2010).

\section{Tourism Climate Index (TCI)}

The concept of the Tourism Climate Index (TCI) was designed by Mieczkowski in 1985 . The method and concept proposed by Mieczkowski aims to assess the implications of future climate change on the relative comfort level of visitors in an area, especially in tourism. Climate variables are combined into five parameters, three of which are independent and the other two are bioclimatic combinations. Climate variables used in TCI are maximum temperature, average temperature, minimum relative humidity, relative humidity, rainfall, duration of irradiation and wind speed. (Table 1).

Table 1. Parameters that use in TCI method

\begin{tabular}{|c|c|c|c|}
\hline $\begin{array}{l}\text { Sub- } \\
\text { Indeks }\end{array}$ & $\begin{array}{l}\text { Climate } \\
\text { variable } \\
\text { by month }\end{array}$ & $\begin{array}{l}\text { Impact of } \\
\text { TCI index }\end{array}$ & $\begin{array}{l}\text { weighting } \\
\text { for TCI }\end{array}$ \\
\hline $\begin{array}{l}\text { Daytime } \\
\text { Comfort } \\
\text { Index } \\
\text { (CId) }\end{array}$ & $\begin{array}{l}\text { Maximum } \\
\text { temperatu } \\
\text { re and } \\
\text { minimum } \\
\text { temperatu } \\
\text { re }\end{array}$ & $\begin{array}{l}\text { shows } \\
\text { thermal } \\
\text { comfort } \\
\text { when } \\
\text { maximum } \\
\text { tourist } \\
\text { activities } \\
\text { occur }\end{array}$ & $40 \%$ \\
\hline
\end{tabular}

\begin{tabular}{|c|c|c|c|}
\hline $\begin{array}{l}\text { Daily } \\
\text { Comfort } \\
\text { Index } \\
\text { (CIa) }\end{array}$ & $\begin{array}{l}\text { average } \\
\text { air } \\
\text { temperatu } \\
\text { re and } \\
\text { average } \\
\text { humidity }\end{array}$ & $\begin{array}{l}\text { showing } \\
\text { thermal } \\
\text { comfort for } \\
24 \text { hours, } \\
\text { including } \\
\text { during sleep }\end{array}$ & $10 \%$ \\
\hline Rainfall & $\begin{array}{l}\text { Percipitati } \\
\text { on }\end{array}$ & $\begin{array}{l}\text { representing } \\
\text { negative } \\
\text { values } \\
\text { related to } \\
\text { outdoor } \\
\text { activity }\end{array}$ & $20 \%$ \\
\hline Sunshine & $\begin{array}{l}\text { Sun } \\
\text { exposure }\end{array}$ & $\begin{array}{l}\text { rated as a } \\
\text { positive } \\
\text { value in } \\
\text { tourism, but } \\
\text { can be } \\
\text { negative } \\
\text { because of } \\
\text { the danger } \\
\text { of sunburn } \\
\text { and } \\
\text { discomfort } \\
\text { during hot } \\
\text { conditions }\end{array}$ & $20 \%$ \\
\hline Wind & $\begin{array}{l}\text { wind } \\
\text { velocity } \\
\text { average }\end{array}$ & $\begin{array}{l}\text { variable that } \\
\text { depends or } \\
\text { has } \\
\text { influence on } \\
\text { temperature }\end{array}$ & $10 \%$ \\
\hline
\end{tabular}

\section{Effect of Climate on Tourism Visits}

Tourism is one sector that is very vulnerable to climate change (Amelung et al. 2007, 8). The existence of climate change can result in a climate that was initially considered comfortable for tourists to become uncomfortable again, which has implications for the pattern of tourist visits to a tourism destination (Suwarto, 2011). The comfort of climate in tourism places is no longer obtained by tourists. So, these tourists will not come back to the tourist attraction.

\section{Methods}

In general, the tourism climate indices can be categorized to three categorized (Mieczkwoski, 1985). That index can be combined as Tourism Climate Index that combined of seven parameters, three of which independent and two in a bioclimatic combination:

$$
\mathrm{TCI}=4 \mathrm{CId}+\mathrm{CIa}+2 \mathrm{R}+2 \mathrm{~S}+\mathrm{W}
$$

Annotation:

TCI : Tourism Climate Index

CId : Daytime Comfort Index, consisting of maximum air temperature $\left({ }^{\circ} \mathrm{C}\right)$ and the mean maximum relative humidity (\%)

CIa : Daily Comfort Index, consisting of mean air temperature $\left({ }^{\circ} \mathrm{C}\right)$ and the mean relative humidity $(\%)$

$\mathrm{R}$ : Rainfall, precipitation (mm)

W : Wind, mean wind speed $(\mathrm{m} / \mathrm{s})$

Data from each parameter obtained from globalwheater.com. The data used in this TCI is calculated on average per month then mapped using GIS. 
This data is then made into a raster format with IDW tools. Each of these parameters is then calculated per month with the raster calculator tool with the TIC equation. In contrast to other climate indices, every contributing parameter is assessed. Because of a weighting factor (a value for TCI of 100), every factor can reach 5 points (Table 2.). The TCI value classification results are then mapped monthly, so that they can be analyzed further in relation to the number of visitors each month.

Table 2. Rating categories of the Tourism Climatic Index

\begin{tabular}{lll}
\hline TCI score & Category & Mapping category \\
\hline $90-100$ & Ideal & Excellent \\
$80-89$ & Excellent & Very good and good \\
\hline $70-79$ & Very good & Acceptable \\
$60-69$ & Good & \\
\hline $50-59$ & Acceptable & \\
$40-49$ & Marginal & Unfavourable \\
\hline $30-39$ & Unfavourable & \\
$20-29$ & Very unfavourable \\
$10-19$ & Extremely unfavourable \\
$\leq 10$ & Impossible & (Mieczkowski 1985)
\end{tabular}

The climate comfort level of tourist destinations in Samosir Regency can be analyzed by looking at the results of TCI value calculations in 7 tourist objects using the climatic elements above. The monthly distribution chart of TCI values is used to help describe and compare TCI values at 7 tourist object. The relation between climate comfort level and number of visits to tourist destinations can be analyzed by looking at the correlation test results between the number of visits and TCI values. Data processing to see whether there is a correlation between the TCI value and the number of visitors is done by conducting a Spearman Rank correlation test.

\section{Result}

TCI index per month in Samosir District.

Based on the calculation of TCI values, the climate comfort value in Samosir Regency has a range of $67-85$. The highest TCI value occurred in February. The TCI value range for this month ranges from 77 (Very Good) to 85 (Excellent). While the lowest is in March with a value range of TCI 67 to 75 (Good) (Fig. 2).

Changes in the value of TCI in Samosir Regency can't be separated from changes in climate patterns. The most easily identified from this climate pattern is rainfall patterns. Rainfall patterns in the Regency are affected by equatorial types. The pattern of changes in TCI values in several tourism destinations shows that there is a pattern similar to the pattern of rain (Fig.3). The rainfall pattern in Samosir Regency has two peaks (Tjasjono, 2003). The pattern showed an increase in February, then dropped to its lowest point in June, and again increased at its second peak in October (fig.4).

In general, Samosir District has a climate comfort level for tourism to go into comfortable conditions. Climate comfort in Samosir must be maintained by maintaining existing land use conditions. The development of tourism in Samosir District will be better directed at developing ecotourism that maintains its environmental conditions.

\section{Correlation of TCI Value and Tourism Visits}

Relation of climate comfort level to the number of visits to tourist destinations is seen by conducting a correlation test. Based on correlation calculations using the quantitative analysis method Spearman's Rho. The monthly distribution chart of TCI values is used to help describe and compare TCI values at 7 tourist object that are Air Terjun Efrata, Menara Pandang Tele, Aek Sipitudae, Batu Sawan, Aek Rangat, Pantai Pasir Putih Parbaba, and Pantai Situngkir. Distribution of 7 tourism destination served in (Fig. 4). Selected tourist attraction is a leading tourist attraction category.

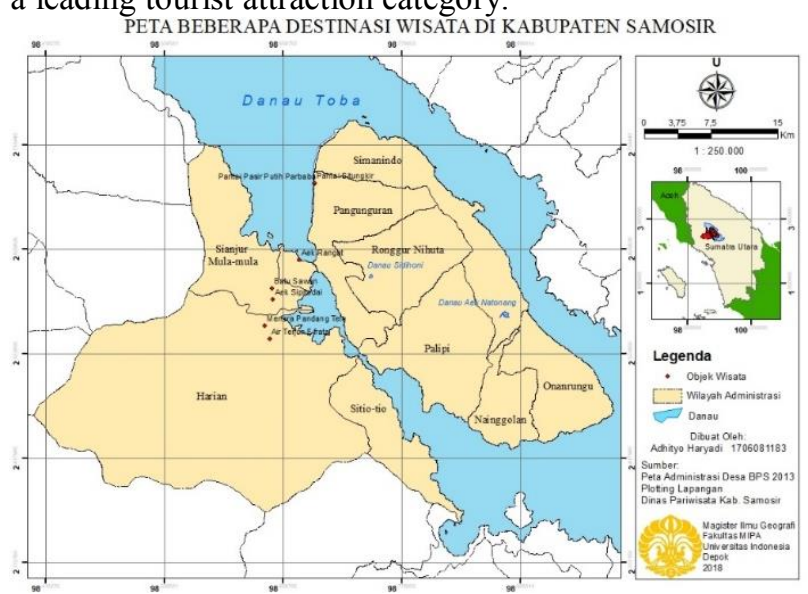

"Figure 4. Distribution of selected tourism destination

Tourism destinations that have high visits are located on the edge of the national road and become the main road both to Samosir Island and to the one from Samosir Island. In addition, this attraction has attractions that can attract tourists. Changes in the number of visitors in each tourism destination can be seen in fig 5. The change follows the holiday season.

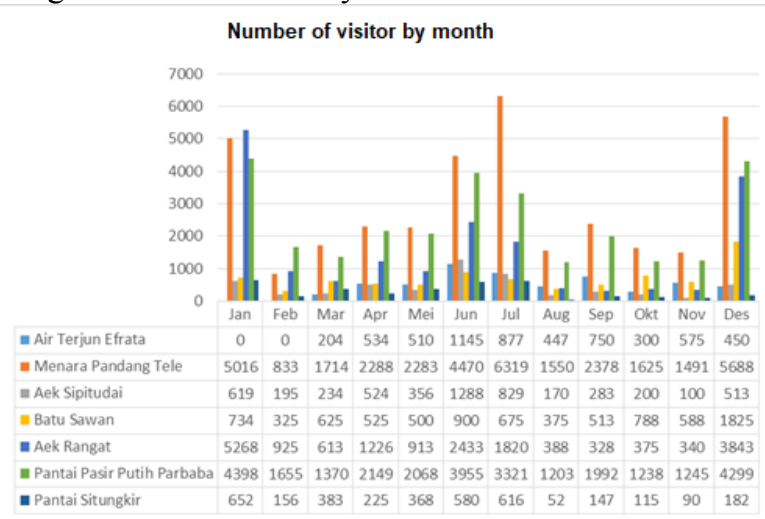

Figure 5. Number of visitors of selected tourist destination by month

The results of the correlation test between the number of visits and TCI values were conducted to determine whether there was a correlation between the level of comfort of the tourist destination area and the number of visitors who came to the tourist attraction. Based on the calculation of correlation using quantitative analysis method Spearman's Rho shows a significance value of 0.253 , where this value is greater than the degree of trustworthiness $=0.05$. So, if Sig. $>0.05$ means there is no correlation between the number of visitors with TCI values at some points of tourism destinations (Tab.3). 


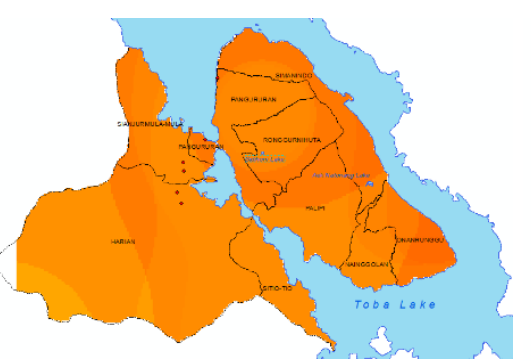

January

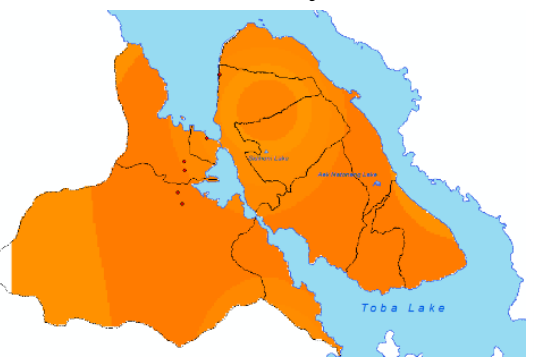

April

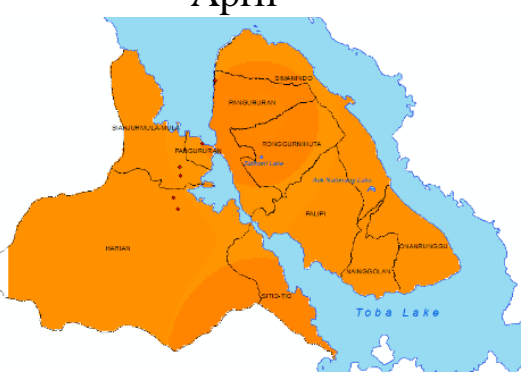

July

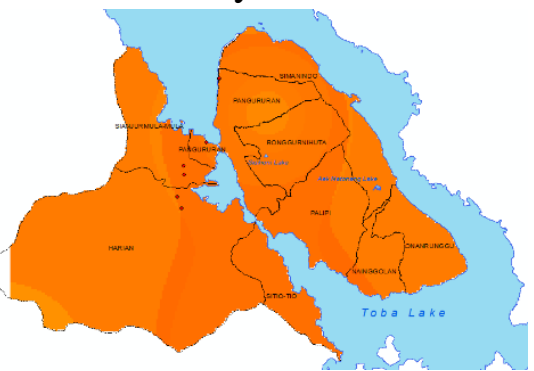

October

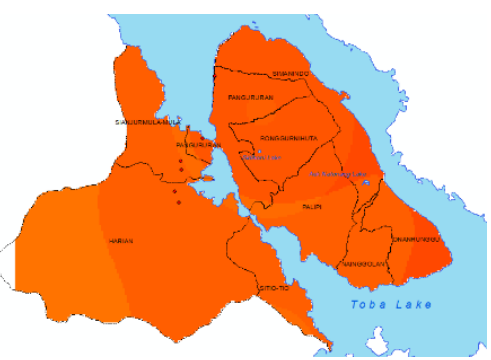

February

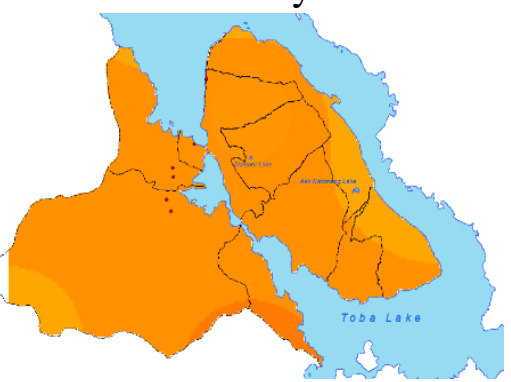

May

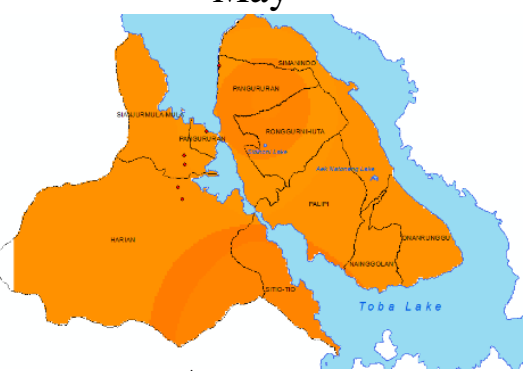

August

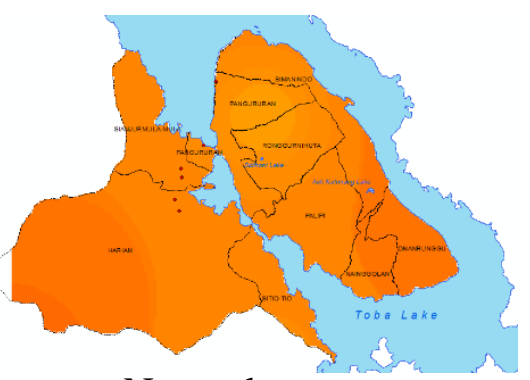

November

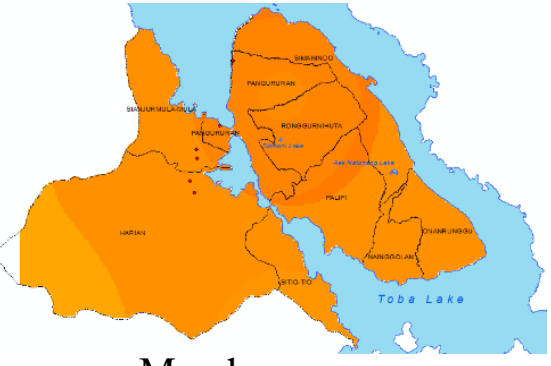

March

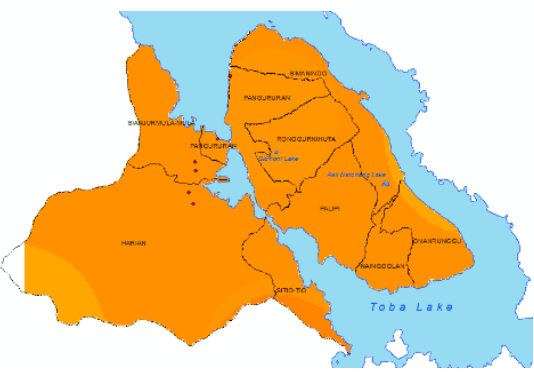

June

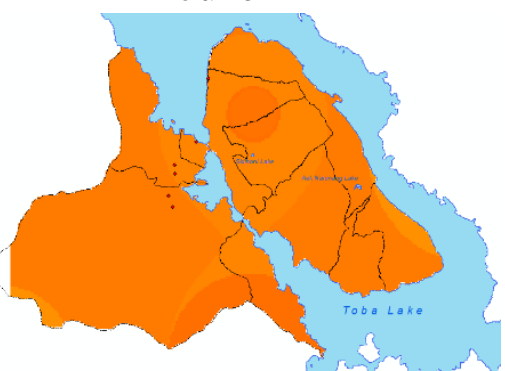

September

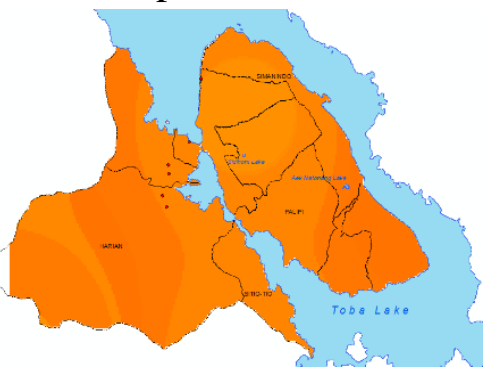

December

Figure 2. TCI Index by month in Samosir District.

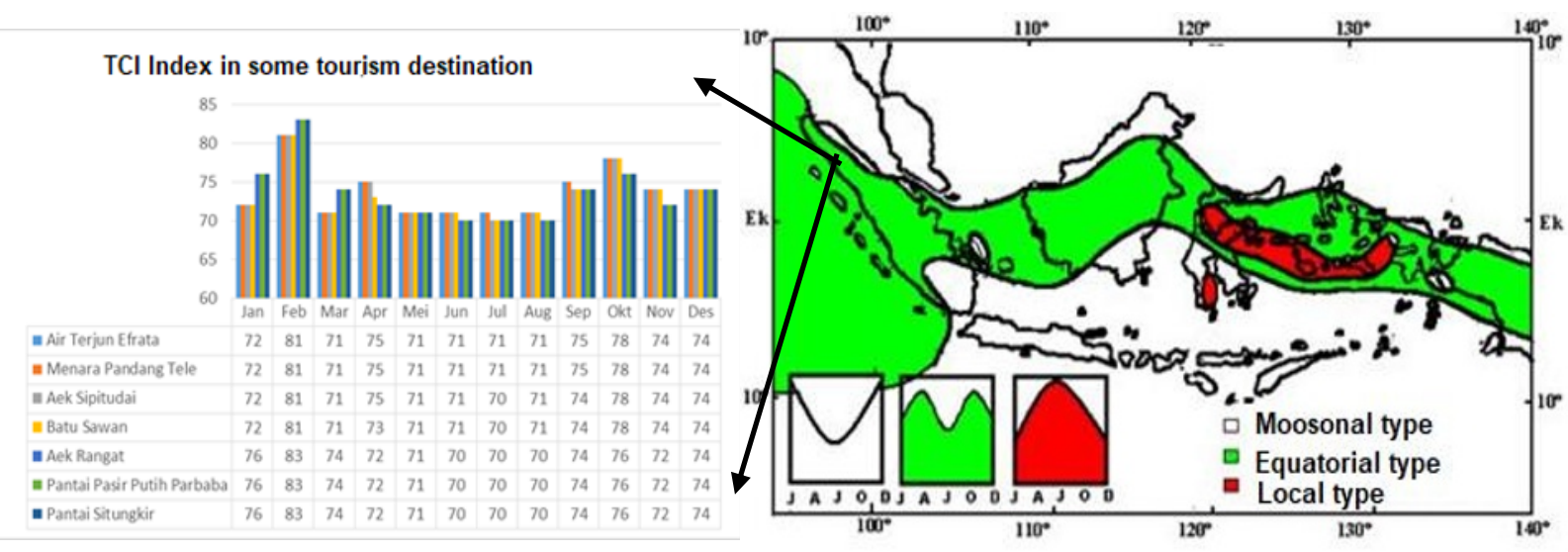

Figure 3. Spatial precipitation patterns in Indonesia and Samosir 
Table 3. Correlation between the number of visitor and TCI index.

Correlations $^{a}$

\begin{tabular}{|lll|r|r|}
\hline & & \multicolumn{1}{c|}{$\begin{array}{c}\text { Jumlah } \\
\text { Pengunjung }\end{array}$} & Nilai TCl \\
\hline Spearman's rho & Jumlah Pengunjung & Correlation Coefficient \\
& Sig. (2-tailed) & 1.000 & -.126 \\
\cline { 2 - 5 } & Nilai TCl & $\begin{array}{l}\text { Correlation Coefficient } \\
\text { Sig. (2-tailed) }\end{array}$ & -.126 & 1.000 \\
\hline
\end{tabular}

a. Listwise $\mathrm{N}=84$

\section{Conclusion}

Based on the discussion above, it can be concluded several things to answer the objectives of this study, is:

1. The comfort value of climate in Samosir Regency has a range of $67-85$. Variations in the range of values per month vary, one of which affects is the regional climate pattern in North Sumatra which is included in the equatorial rain pattern.

2. Based on the climate comfort index value map above, the right time to travel to Samosir Regency is in February.

3. There is no correlation between the number of visitors and TCI values at some tourism destination points.

\section{Acknowledgement}

Although climate comfort does not have a correlation with the number of visitors, it is still necessary to control exhaust emissions which will affect the increase in temperature and disruption to the amenities of tourists. The impact will further affect the cultural tourism attractions that are relied on by the local community through Batak culture.

To be able to advance tourism in Samosir Regency, the local government must be able to innovate tourism attractions in Samosir Regency, such as organizing cultural and culinary festivals in several existing tourist attractions. In addition, tourism promotion must be intensified as information for visitors to attract interest in visiting other tourism destinations. Factors supporting tourism such as supporting facilities and souvenir shops must also be reproduced.

\section{Reference}

1. Gumelar, G. Ekonomi. Retrieved from cnnindonesia: https:/www.cnnindonesia.com/ekonomi/201710181 80443-78-249279/kemenpar-klaim-pariwisata-jadikontributor-utama-devisa. (2017, October 19)

2. Kabupaten Samosir. Geografis. Retrieved from samosirkab.go.id: https://samosirkab.go.id/web/geografis/ (2014, April, 3)
3. Mieczkowski, Z. (1985). The tourism climate index: A method for evaluating world climates for tourism. - The Canadian Geographer 29: 220-233

4. Rilatupa, J. (2008). Aspek Kenyamanan Termal Pada Pengkondisian Ruang Dalam. Jurnal Sains dan Teknologi EMAS.

5. Scott, D. \& Lemieux, C. (2010). Weather and Climate Information for Tourism. Procedia Environmental Sciences. 1, 146-183.

6. Suwarto, T. (2011). Pengaruh Iklim dan Perubahannya Terhadap Destinasi Pariwisata Pantai Pangandaran. Jurnal Perencanaan Wilayah dan Kota, 17-32.

7. Tjasjono. B., (2003). Klimatologi. Bandung : ITB 